\title{
Az érzelmi intelligencia vizsgálata a szervezeti kultúra tükrében
}

\author{
Kutatási beszámoló
}

\section{Emotional Intelligence Assessed in Organisational Culture}

Research Report

\begin{abstract}
o.
Összefoglalás

A tanulmányban bemutatott empirikus kutatáshoz 572 fó szolgáltatott adatot, összesen 26 iskolából. Az iskolák között 18 általános iskola, 7 középszintú képzőintézmény és 1 általános és középiskola szerepelt. A kutatás fó kérdése a pedagógusok érzelmi intelligenciájának mintázatára vonatkozott, arra, hogy az egyes intézmények oktatói az adott intézmény szervezetikultúra-típusának függvényében mutatnak-e eltérést az egyéni érzelmiintelligencia-mintázatukban. Vizsgáltuk, hogy a szervezeti kultúra milyensége hatással van-e az egyén érzelmiintelligencia-mintázatának alakulására. Az eredmények alapján elmondható, hogy adott szervezetikultúra-típussal rendelkezó intézmény oktatói eltérố érzelmiintelligencia-mintázatokkal rendelkeznek. Az eltérô mintázat okaként sikerült azonosítani azon összefüggéseket, amelyek az iskola szervezeti kultúrája és az oktató(k) érzelmi intelligenciája között megragadhatók.
\end{abstract}

Journal of Economic Literature (JEL) kódok: D91, E71, M14

Kulcsszavak: szervezeti kultúra, érzelmi intelligencia, iskolai szervezet

Dr. Balázs LÁszló PhD, intézetigazgató egyetemi docens, Dunaújvárosi

Egyetem, Társadalomtudományi Intézet (balazsı@uniduna.hu). 


\section{Summary}

Data was collected from 572 persons from 26 schools for the empirical research described in the study. Among the schools, 18 were primary schools, 7 secondary schools and 1 combined primary and secondary educational institution. The primary question of the research focused on the emotional intelligence pattern of the teachers, more specifically whether the teachers of the individual institutions showed any differences in their emotional intelligence patterns in relation to the organisational culture type of the given institution. We examined if the type of the organizational culture could have an effect on the development of the individual's emotional intelligence pattern. Based on the results it can be stated that the teachers in the individual institutions with specific types of organisational culture have different kinds of emotional intelligence patterns. As the reason for the diverse patterns, the interrelationships between the organisational culture of the given school and the teachers' emotional intelligence were established.

Journal of Economic Literature (JEL) codes: D91, E71, M14

Keywords: organizational culture, emotional intelligence, school organization

\section{BEVEZETÉS}

A hazai szervezetpszichológia-kutatók érdeklódése az iskolai szervezetek vizsgálata iránt a 90-es évek második felétól kezdett el növekedni. A 90-es években a közoktatás nagy változásokon ment keresztül, és a változó kornak megfelelôen napjainkban is hasonló változásokat él meg. A 90-es évek elôtt a központi irányítás számára nem volt fontos az egyes intézmények sajátosságainak - erôsségeinek, gyengeségeinek vizsgálata. Azonban a rendszerváltozással, az iskolák irányításának átstrukturálásával ez a szemléletmód megváltozott. A változást segítette a szabad iskolaválasztás által is erôsített verseny kialakulása az egyes intézmények között, melyet a diákság létszámának radikális csökkenése is nagymértékben befolyásolt. Felismerték, hogy a gazdasági szférához hasonlóan a közoktatás intézményeinél is fontos a szervezeti sajátosságok vizsgálata, illetve figyelembevétele az egyes döntések meghozatalánál. Az elmúlt időszakban, a 90-es évekhez hasonlóan, újfent nagy átalakítások zajlottak a közoktatásban, melyek összevonásokkal, átszervezésekkel, iskolarészek más intézményhez való átcsatolásával jártak. Az iskolai szervezeteknek újabb kihívással kell megküzdeniük. Az elmúlt idôszak és napjaink közoktatás-politikai változásai, az intézmények átszervezésének problematikája, a változást megélt intézmények gördülékeny múködtetésének biztosítása egyre növeli az igényt ezen szervezetek, szervezettípusok szervezetpszichológiai jelenségvilágának feltárására.

Habár az igény már jóval korábban jelentkezett, és napjainkra csak fokozódott, ilyen irányú vizsgálatok mégis csekély számban láttak napvilágot. Éppen ezért a nyilvánvaló társadalmi mellett tudományelméleti relevanciával is bír a terület alaposabb 
vizsgálata. Gondoljunk csak arra a tényre, hogy például az oktatási rendszer legalsó szintjén lévô iskolák minden formalizált meghatározottságuk ellenére jelentôsen különböznek egymástól - minden intézménynek megvan a maga arculata, a maga kultúrája. Ezen eltérések feltárását Halász Gábor 1980-ban írt, az iskola szervezeti klímáját elemzó munkája kezdte meg. A szervezet környezetének, légkörének vizsgálata mellett a 90-es években újabb pszichológiai fogalmak megragadására vállalkoztak a kutatók, melyek tovább hangsúlyozták az intézmények egyediségét. Az ezredforduló környékén Mészáros Aranka (2002) szerkesztésében megjelent egy összegzó munka, amely az iskola általános, szociálpszichológiai jelenségvilágába enged betekintést. A szervezetpszichológusok érdeklôdni kezdtek az iskola belsố világának vizsgálata iránt. Az iskolai klímakutatások mellett az iskolai szervezetek vizsgálatának másik meghatározó dimenziója a szervezetikultúra-kutatás lett. Ennek eredményeként az ezredfordulón több, az iskolai szervezet kultúráját elemzô, többségében empirikus megalapozottságú tanulmány született (pl. Szabolcsi, 1996; Kovács, 1996; Baráth, 1998; Kovács et al., 2005; Serfőző 2002; 2005).

Míg a kultúra vizsgálata jellemzóen az antropológusok tárgykörébe tartozik, addig a szervezeti kultúra elemzése elsôsorban a szervezetpszichológia feladata. A kultúra fogalmának szervezetekre történó alkalmazása több, a nemzeti kultúra kapcsán körvonalazódott vizsgálati szempontot, módszert kínált a szervezetkutatók számára. A kultúrával - részben vagy teljesen - foglalkozó szakirodalomban több olyan kutatóval találkozhatunk, akik az érzelmek és a kultúra kapcsolatát vizsgálták: Darwin (1859/2000), Geertz (1973/1994), Levy (1984), Lutz (1986), Ekman (1989). A vizsgálatokkal párhuzamosan az érzelmek elemzése a társadalom, a kultúra megismerésének, az antropológiának és a pszichológiának a jellegzetes kutatási területévé vált. Napjainkra a szervezetpszichológiai vizsgálatok kapcsán is egyre több olyan munkát publikálnak, amelyek az érzelmek szerepét vizsgálják a szervezet múködésében, a munkahelyen (Gibson, 2006; Payne-Cooper, 2004; Lazányi, 2011). Az érzelmek vizsgálata mellett egyre markánsabban jelentek meg azok a munkák is, amelyek az érzelmek kezelésére, alkalmazására, az érzelmek információfeldolgozásban játszott szerepére vonatkoztak (Forgács, 2001, 2003; Oláh, 2005). A 20. század végére új kutatási terület körvonalazódott, amely az érzelmek érzékelésének, feldolgozásának, kezelésének és alkalmazásának folyamatát jelölte meg vizsgálata tárgyaként: ez az érzelmi intelligencia vizsgálatának területe.

A két konstruktum szakirodalmának tanulmányozása kapcsán vált egyértelmúvé számunkra, hogy a szervezeti kultúra és az egyén érzelmi intelligenciája közötti kapcsolat feltárása elméleti és társadalmi relevanciával egyaránt rendelkezik, felhívva a figyelmet ezek iskolai szervezetekben történô vizsgálatának fontosságára. Az érzelmek és a kultúra kapcsolatára vonatkozó vizsgálatok alapján - számba véve a nemzeti kultúra és a szervezeti kultúra összefüggéseit (pl. Hofstede-Hofstede, 2008) - nyilvánvaló, hogy az érzelmi intelligencia és a szervezeti kultúra között is található valamilyen kapcsolat.

Tanulmányunkban a szervezeti kultúra és az egyéni érzelmi intelligencia közötti kölcsönös kapcsolatot vizsgáljuk, párhuzamba állítva a szervezeti kultúra sajátosságait az egyén érzelmi intelligenciájával. Az említett fogalmak külön-külön vizsgálata mellett 


\section{Balázs László: Az érzelmi intelligencia vizsgálata a szervezeti kultúra tükrében}

az együttes, egymásra gyakorolt hatásukat csak részben vagy egyáltalán nem elemezték. A fogalmak tisztázását és a vonatkozó vizsgálati eredmények bemutatását követôen a tanulmány második fele részletezi az elvégzett vizsgálatot és annak eredményeit.

\section{ÉRZELMI INTELLIGENGIA}

Az érzelmi intelligencia tanulmányozása részben a megismerés és az érzelmek kutatásának határterületén rajzolódott ki, olyan területen, amelyet az a kérdés foglalkoztatott, miként formálja át az érzelem a gondolkodást, és viszont. Az ilyen irányú kutatások fejlôdésének egyik eredménye volt az érzelmi intelligencia koncepciója, az a felismerés, hogy az érzelmek és az értelem egymással együttmúködve sokkal kifinomultabb információfeldolgozásra képesek, mint bármelyik külön-külön.

A fogalom elsố publikálása óta több, sokszor egymástól jelentôsen eltéró érzelmiintelligencia-definíció és -modell született. Pérez, Petrides és Furnham (2005) munkájukban összegzik az addig publikált definíciókat és azok tartalmát, valamint bemutatják a konstruktumok mérésére kidolgozott eszközök jellemzőit. A modellek alapvetố különbsége abban nyilvánul meg, hogy mit sorolnak az érzelmi intelligencia tartományához. Az Encyclopedia of Applied Psychology az érzelmi intelligencia három fố modelljét különbözteti meg.

1. A Mayer-Salovey-modell meghatározza magát a konstrukciót. Úgy definiálja, mint a képesség arra, hogy érzékeljük, megértsük, kezeljük és használjuk az érzelmeket, amelyek megkönnyítik a gondolkodást.

2. A Goleman-modell egy sor érzelmi és szociális kompetenciát sorakoztat föl, amelyek hozzájárulnak a vezetési teljesítményhez.

3. A Bar-On-modell leírja az érzelmi intelligenciát mint az összefüggó szociális és érzelmi kompetenciák keresztmetszetét. Ezek olyan kompetenciák, készségek és moderátorok, amelyek hatással vannak az intelligens viselkedésre (Spielberger, 2004).

\section{Érzelmi intelligencia az iskolában}

Az érzelmi intelligencia iskolai alkalmazására a hazai szakirodalomban igen kevés munka található, ugyanakkor számos, egymástól eltéró megközelítéssel találkozhatunk. A diákok érzelmi intelligenciájának fejlesztési lehetôségére fókuszál Szitó (2009), a nevelőmunkában betöltött szerepét taglalja Hegyiné (2009), míg Kádár (2012) a kisiskoláskorúak érzelmi intelligenciájának a fejlesztését tartja szem elôtt. Emellett a pedagógiai szakirodalomban több olyan elemzés is fellelhetô (pl. Hegyiné, 2001), amely a már meglévó érzelmiintelligencia-elméleteket abduktív módon igyekszik alkalmazni az oktatás-nevelés valamely folyamatában. Találunk példát arra is, hogy az érzelmi intelligencia és az iskolai szervezet szervezetpszichológiai jellemzóivel kapcsolatos összefüggések feltárására vállalkoznak a kutatók (pl. Balázs, 2013; Péter-Szarka-Fehér, 2012).

A nemzetközi szakirodalomban az érzelmi intelligencia pedagógiai irányultságú elemzése nagy népszerúségnek örvend, problémacentrikus (Roberts et al., 2010) és összefoglaló jellegú munkákat (Mortiboys, 2005; Coetzee-Jansen, 2007) egyaránt 
találhatunk. A szervezetpszichológia nemzetközi szakirodalmát vizsgálva jól látható, hogy habár az érzelmi intelligencia különbözó szervezeti kontextusú vizsgálatáról valószínúleg Goleman munkásságának is köszönhetóen - szép számmal készültek tanulmányok, az iskolai vonatkozások elemzésére itt is csak érintőlegesen kerül sor.

Pauwlik és Margitics (2008) pedagógusjelöltek érzelmi intelligenciáját vizsgálta, Bar-On megközelítését alapul véve. Vizsgálatukban megállapították, hogy a pedagógusjelöltek leginkább az interperszonális képességeket, legkevésbé az adekvát stresszkezelést tartják magukra jellemzônek.

Baracsi (2013) munkájában a pedagógusok érzelmiintelligencia-mintázatát vizsgálta $(\mathrm{N}=700)$. Eredményei szerint a vizsgálatban részt vevố pedagógusok fóképp az érzelmek felismerésében és szabályozásában mutatnak rosszabb teljesítményt. A kapcsolati készségek terén hatékonyabbak a tanárnôk, a pályájukon legrégebben lévốk és a munkájukkal elégedett pedagógusok, a törôdés legkevésbé a gimnáziumi tanárokra jellemzô. Az érzelmek szabályozása a középgeneráció, illetve a szakoktatók számára okoz inkább nehézségeket.

\section{AZ ISKOLA SZERVEZETI KULTÚRÁJA}

A közoktatási intézmények szociálpszichológiai és szervezetpszichológiai vizsgálata a hazai és a nemzetközi kutatók érdeklődésének középpontjában állt az elmúlt két évtizedben. Számos vizsgálatot és eredményt publikáltak, melyek az iskola szervezeti kultúrájának összefüggéseit tárták fel. A hazai vizsgálatok során a leggyakrabban a Quinn és Rohrbaugh által kidolgozott (1983) „versengó értékek” szervezetikultúra-modellt alkalmazzák a kutatók. A vizsgálat során mi is ezt a modellt alkalmaztuk, így ezt a következókben részletesen ismertetjük. Az elnevezés arra utal, hogy a szervezetek különféle értékekre koncentrálva törekednek hatékonyságuk, eredményességük növelésére. A modell egy háromdimenziós szervezeti keretet határoz meg a hatékony szervezetekre vonatkozóan:

1. a szervezet fókusza lehet belsô, személyorientált, vagy külsô, szervezetorientált;

2. a szervezeti kultúrával kapcsolatban lehet stabilitást preferáló, és/vagy előnyben részesítheti a rugalmasságot;

3. a vágyott célok elérése kapcsán a hangsúly lehet az eszközön, amellyel a célt eléri, vagy fókuszálhat a célra.

Az elsố két dimenzió a szervezeti kultúra hatékonyságával kapcsolatos négy alaptípust írja le, míg a harmadik az ezeken belüli eszköz- vagy célorientált szemléletmódot határozza meg. Quinn két tengely - kontrolláltság, illetve a belsố és külsô fókusz mentén helyezte el a négy típust, melynek eredményeként a következố szervezetikultúra-típusokat kapta.

A szabályorientált kultúratípusban jól definiált szerepek alakulnak ki. A legfóbb elvárás, hogy kövessék a szabályokat. Fontos a formális pozíciók tisztelete. Ezt a modellt a befelé irányultság, a kontrollálás és az ellenôrzés magas foka jellemzi, ez rendet, kiszámíthatóságot, stabilitást, egyensúlyt eredményez. Két fontos folyamat tartozik ide: a dokumentálás és a stabilizálás. Ennek tükrében a vezetô két elsôdleges szerepe a 


\section{Balázs László: Az érzelmi intelligencia vizsgálata a szervezeti kultúra tükrében}

megfigyelés és a koordinálás. Monitorként tudja, hogy mi történik a szervezetben, a koordinátortól pedig elvárják, hogy fenntartsa a szervezet egészének struktúráját, és biztosítsa múködését. Ezzel szemben az innovatív kultúrában a kreativitáson és a kockázatvállaláson van a hangsúly. Az információ szabad áramlása, a teammunka és a tagok állandó továbbképzése jellemzi. A tagokat nem ellenôrzik, hanem lelkesítik, ösztönzik. A kifelé irányultság mellett a kontrolláltság kismértékú. Legfőbb erôssége az alkalmazkodóképesség és a változni tudás. A vezetô két fố szerepe: az innovátor és a bróker. Az innovátor feladata, hogy felismerje és elômozdítsa a szükséges változásokat. A bróker pedig a külsố legitimitás fenntartására törekszik.

A célorientált kultúra esetében a hangsúly a profiton, a produktivitáson, a hatékonyságon van. A feladatok tisztázása, a célok kitúzése a legfontosabb ebben a szervezettípusban. A kontroll, az ellenôrzés magas foka és a kifelé irányultság jellemzi. Meghatározó az eredményességre törekvés és az irányítás-utasítás. A vezetố két elsôdleges szerepe: a direktor és a producer. Direktorként a vezetố megfogalmazza az elvárásokat, míg producerként a feladatra, a munkára összpontosít, érdeklốdik a beosztottak felól, motiválja óket. Ezzel szemben a támogató kultúra az egyetértést, az összetartást, a csapatmunka szerepét és fontosságát hangsúlyozza, fontos szerepet juttatva a belsố kontrollnak is. Ebben a kultúrában az emberi erőforrásokon, az egyéni fejlődés lehetôségén és az elkötelezettségen van a hangsúly. Ez a szervezeti kultúra a belső folyamatokra figyel, ugyanakkor rugalmas. A vezetô két elsôdleges szerepe: a facilitátor és a mentor. A facilitátortól azt várják, hogy segítse elő az együttes erôkifejtést, míg a mentortól a tagok képességeinek, készségeinek fejlesztését, tréninglehetôségek biztosítását várják. A mentor segít megtervezni az alkalmazottak egyéni fejlődését (Bíró-Serfőző, 2003).

A szervezeti kultúra vizsgálatának fontosságát egyaránt hangsúlyozzák a hazai és nemzetközi vizsgálatok. A vizsgálatok - amellett, hogy azonosítottak jellemzó iskolai kultúratípusokat - összefüggést mutattak ki a szervezeti kultúra és a szervezet mérete (Szabolcsi, 1996), az eredményesség (Gaziel, 1997; Arshad, 2003), a kultúra észlelése (Baráth, 1998) és a szervezeti tagok elköteleződése (Wang-Hwang, 2007) között.

\section{A SZERVEZETI KULTÚRA ÉS AZ ÉRZELMI INTELLIGENGIA KAPCSOLATA}

Az érzelmi intelligencia szervezeti kontextusban történô vizsgálata elsôsorban a vezetôk sajátosságaira, a hatékonyság és eredményesség kérdésére fókuszál. Az általános, teljes kollektívát megcélzó vizsgálatokra ritkán kerül sor. Emellett az oktatási intézmények vizsgálatával kapcsolatban is elmondható, hogy az érzelmi intelligencia fókusza elsősorban oktatási, módszertani folyamatok kapcsán merül fel a szakirodalomban. A következôkben olyan vizsgálatokat mutatunk be, melyek a kutatás kérdésfelvetésével párhuzamba állíthatók. Igaz, mellózik a közoktatás intézményeinek vizsgálatát - erre a kontextusra vonatkozó elemzéssel nem találkoztunk.

Higgs és Dulewicz (1999) vizsgálataiban egy korábban meghatározott szervezetikultúra-elméletre alapoznak. A Goffee-Jones-féle modell (1998) a szervezetek társadalmi struktúráját vizsgálja, két, koncepcionálisan elkülönüló típusú társadalmi viszonyt, a 
szociabilitást és a szolidaritást illetôen. A szociabilitás például olyan hálózatokra vonatkozik, amelyeket saját döntésünk alapján alakítunk, vagy amelyeket készen kapunk, mint például a családot. Ezek természetes hálózatok, ahol közösek az értékek, hátterek, érdeklődések, családi kötôdések. A szolidaritás a nyilvános szférában meglévô kapcsolatokat írja le. Ezek alapjai közös feladatok, egyértelmú célok és megosztott funkciók. Nem feltétlenül fontos, hogy az emberek szeressék egymást, mindaddig, amíg eredményesen tudnak a kiválasztott cél megvalósításán dolgozni. Mindkét dimenzió lehet pozitív vagy negatív. A vizsgálatuk eredményei arra utalnak, hogy kapcsolat van a szervezeti kultúra és az egyéni érzelmi intelligencia között. Azonban az elôzetes eredmények kiterjesztéséhez és alátámasztásához további, nagyobb mintán végzett kutatások szükségességét vetik fel (Higgs-McGuire, 2001).

Herriford (2002) dolgozatának egyik alapkérdése a környezet és az egyéni érzelmi intelligencia kapcsolatára vonatkozik: Hogyan befolyásolják a környezeti sajátosságok az egyén érzelmi intelligenciájának kialakulását/fejlódését és alkalmazását? Vizsgálatában a megkérdezett vezetôknek arról kellett beszámolniuk, hogy a területen dolgozók közössége hogyan múködik, illetve a közösségi kultúra hogyan befolyásolja az egyén érzelmi intelligenciáját. A jellemzett kultúra olyan szempontokat helyezett előtérbe - például az egyéni teljesítmény, előmenetel -, amelyek vonzóvá teszik az adott kultúrát, ugyanakkor nagyban megnehezítik a kötelezettségvállalást.

A high-tech kultúra a személyes identitást és értékeket helyezi a középpontba, miközben figyelmen kívül hagyja azokat az alternatív kvalitásokat, amelyek elôsegítik a társadalmi szempontból felelósségteljes viselkedést. Ezzel olyan, a szervezetek által hasznosított és módszeresen elôsegített, egyensúly nélküli helyzetet teremt, melyben sajátos fônök-beosztott kapcsolatok alakulnak ki, s azok folyományaként egyfajta torz érzelmi intelligencia, amely az erôs önorientált készségekben, illetve a gyenge másokra irányuló kompetenciákban nyilvánul meg. Az emberi értelem nyújtotta lehetőségek megvalósításának érdekében a szervezeteknek elő kell mozdítaniuk egyensúlyban lévő érzelmi képességek létrejöttét, valamint olyan értékeket kell felkarolniuk, amelyek magukban rejtik az emberi tapasztalat gazdagságát.

\section{A VIZSGÁlat ÉS MódSZERTANi HÁtTERE}

Az érzelmi intelligencia és a szervezeti kultúra vizsgálata is külön-külön a tudományos érdeklődés középpontjában áll. Ugyanakkor a kettő közötti kapcsolat feltárására jellemzóen csak abduktív okfejtéssel történt kísérlet (pl. Higgs-Dulewicz, 1999). Oktatási intézmények tekintetében a két konstruktum vizsgálatára vonatkozóan nem találtunk empirikus vizsgálatot.

A kutatási kérdései: Kimutatható-e kapcsolat a szervezeti kultúra és az érzelmi intelligencia között? A szervezeti kultúra egyes dimenziói milyen érzelmiintelligencia-tényezőkkel mutatnak összefüggést?

A kutatás hipotézise: Az eltérô szervezetikultúra-típusok eltérô érzelmiintelligencia-mintázatot preferálnak. Herriford (2002) vizsgálatai alapján elmondható, hogy az iskola szervezeti kultúrája a kulturális sajátosságoknak megfelelô érzelmiintelligen- 
cia-tényezôket támogat. Ennek megfelelôen jól leírható lesz az egyes kultúratípusok - kultúradimenziók - és az azok által támogatott érzelmiintelligencia-tényezók kapcsolata. A két konstruktum közötti együttjáráson túl, a szervezeti kultúra és az érzelmi intelligencia között kölcsönhatást lehet majd kimutatni. Elméleti megközelítésben, hosszú távon a szervezeti kultúra változása az érzelmi intelligencia változását eredményezheti, és fordítva, a szervezeti csoport tagjainak egységes érzelmiintelligencia-változása hozzájárulhat a szervezeti kultúra alakulásához.

Vizsgálatunkban a szervezeti kultúra elemzésére két, az érzelmi intelligencia mérésére egy eszközt alkalmaztunk.

\section{Szervezeti kultúra vizsgálata}

A Quinn és Rohrbaugh (1983, idézi Kovács et al., 2005) által kidolgozott „versengő értékek" modelljérôl már szóltunk korábban. Azért erre a kérdôívre esett a választás, mert a magyarországi vizsgálatok jellemzôen ezt a kérdôívet alkalmazzák (Baráth, 1998; Serfőző, 2005; Kovács et al., 2005), emellett a mérôeszköz alkalmazhatóságát Baráth (1998) korábbi munkájában megvizsgálta, és megállapította annak iskolai környezetben való relevanciáját.

Quinn kérdőíve hat kérdéscsoportot fogalmaz meg, ezek

- a szervezet karakterére, alapvetó jellegére,

- a szervezetet összetartó erőre,

- az egység vezetőjére,

- a szervezeti légkörre,

- a siker értékelésére,

- a vezetési rendszerre vonatkoznak.

Minden egyes kérdéscsoporton belül négy állítás található, amelyek az egyes kultúratípusok sajátosságait tükrözik. A válaszadók feladata, hogy százalékosan meghatározzák, melyik állítás mennyire igaz az intézményükre. Kérdésenként 100 pontot oszthatnak szét a négy válasz között. Az egyes kultúratípusra vonatkozó értékeket az arra vonatkozó válaszok pontjának átlagértékéból kapjuk.

A szervezeti kultúra további árnyalását szolgálja a Robbins (idézi Kovács et al., 2005) által kidolgozott, Bakacsi (2015) által kiegészített 11 kultúradimenzió, mely a tagok szervezeti kultúrával kapcsolatos érzéseit meghatározó jellemzókből indul ki. Az elméleti keret alapján a Kovács Zoltán által kidolgozott kérdôívben speciálisan az iskolai környezetre vonatkozóan 22 értékpárral jellemezhetjük a szervezeteket. Minden egyes dimenzióra két-két állításpár vonatkozik. A válaszadók 1-tôl 7-ig jellemezhetik az adott kultúrát annak megfelelôen, hogy az adott állítás mennyire jellemzố a kultúrájukra. Így az egyes értékek dominanciáját a pontszám mérete jelzi. A szervezetre vonatkozó eredményeket az adott értékdimenzióra vonatkozó állítások átlagából kapjuk.

A következô kultúradimenziók észlelését vizsgálja:

1. Munkakörrel vagy szervezettel való azonosulás: A dimenzió két végpontján a szervezettel mint egésszel való azonosulás, illetve bizonyos munkacsoportokkal vagy munkakörrel való azonosulás jelenik meg. 
2. Egyén- vagy csoportközpontúság: Az egyéni vagy a csoportcélok a hangsúlyosabbak. Az egyéni oldalra a szabadság, függetlenség, felelôsség támogatása a jellemzóbb, míg a csoportközpontúság esetén a vezetés a csoportcélokra helyezi a hangsúlyt.

3. Humánorientáció: A feladat- vagy kapcsolatorientált vezetés dimenziója. Szintén a vezetés és a beosztottak viszonyát jellemzi; mennyire figyel a vezetés a szervezeti feladatok megoldásának emberekre gyakorolt következményeire.

4. Belsố függés vagy függetlenség: Az integráció szintjére utal. A szervezeti egységek függetlenségét, valamint a központi koordináció, centralizáció mértékét határozza meg.

5. Erôs vagy gyenge kontroll: A szabályozás, a beosztottak ellenôrzésének közvetlen felügyeletének mértékére utal.

6. Kockázatvállalás-kockázatkerülés: A szervezet bizonytalansággal kapcsolatos toleranciájára utal. Mennyire elvárt vagy támogatott a kockázatkeresô, innovatív magatartás, mennyire túrik a bizonytalanságot.

7. Teljesítményorientáció: A jutalmazási rendszert jellemzi. A jutalmazási rendszer mennyire épít a teljesítményre, illetve milyen mértékben vesz figyelembe más tényezóket.

8. Konfliktustúrés: A vezetést, illetve a szervezetet abból a szempontból jellemzi, hogy mennyire megengedett vagy bátorított az egyet nem értés nyílt felvállalása.

9. Cél-, illetve eszközorientáció: Szintén a vezetést jellemzi abból a szempontból, hogy a szervezeti eredmények vagy a célelérés folyamata kap-e hangsúlyt.

10. Nyílt vagy zárt rendszer: A szervezet és a környezet viszonyát jellemzi. Ebben a dimenzióban a szervezet külsố változásokra való reagálókészsége, illetve ennek hiánya jelenik meg.

11. Rövid vagy hosszú távú időorientáció: A szervezet jövôtervezésének távlatát jeleníti meg.

\section{Az érzelmi intelligencia vizsgálata}

Az érzelmi intelligencia vizsgálatára Bar-On (2006) érzelmiintelligencia-skáláját használtuk. Az érzelmiintelligencia-skála 121 állításból áll. Összesen öt fố tényezôt azonosítanak a kérdések: inter- és intraperszonális érzelmi intelligencia, alkalmazkodó, stresszkezeló és általános hangulati érzelmi intelligencia. Az 5 fố tényezó számos, szorosan kapcsolódó kompetenciát, készséget és moderátort tartalmaz. Kitöltéskor a válaszadónak 1-tôl 5-ig kell az egyes állításokat értékelnie aszerint, hogy azok mennyire igazak rá. Az egyes metatényezők eredményét az ahhoz tartozó itemek átlaga adja. A fố tényezôk értékét a metatényezók átlagértéke képezi.

Intraperszonális készségek (öntudat és önkifejezés):

- magabiztosság: érzéseink és önmagunk határozott kifejezése;

- érzelmi öntudat: az érzelmeink megértése;

- önbecsülés: tudatában lenni annak, hogy megértjük és elfogadjuk magunkat;

- függetlenség: önálló és másoktól független, szabad érzelmek kialakítása;

- önmegvalósítás: a potenciális célok meghatározása és megvalósítása, aktualizálása.

Interperszonális készségek (társadalmi tudatosság és interakció):

- empátia: annak tudatos kezelése és megértése, hogy mások hogyan érzik magukat; 


\section{Balázs László: Az érzelmi intelligencia vizsgálata a szervezeti kultúra tükrében}

- társadalmi felelôsségvállalás: érzelmi és szociális azonosulás más társadalmi csoportokkal;

- interperszonális kapcsolat: kölcsönösen kielégító.

A stressz kezelése:

- stresszkezelés: érzelmeink hatékony és építô jellegú irányítása;

- az ösztönös késztetések irányítása/impulzuskontroll: érzelmeink hatékony és építố jellegú kontrollálása.

Alkalmazkodóképesség:

- valóság tesztelése: érzelmeink tesztelése és a valós gondolkodással való párhuzamba állítása;

- rugalmasság: a változásokkal való megküzdés, alkalmazkodás a mindennapi életben;

- problémamegoldás: a problémák hatékony megoldása intraperszonális és interperszonális helyzetekben.

Általános hangulat (önmotiváció):

- optimizmus: pozitív kilátások észlelése;

- boldogság: érzés, amely szerint általában elégedettek vagyunk magunkkal, másokkal és az élettel.

A vizsgálati személyek

A vizsgálat kapcsán általános és középiskolákat kerestünk fel. Tekintettel a mai közoktatás hektikus állapotára, az iskolák többsége visszautasította a kutatásban való részvételt. A munkahelyi és magánkapcsolatok révén sikerült több iskolához eljutni, ahol szívesen kitöltötték a kérdôíveket. Összesen 26 iskolát vizsgáltunk meg. Az iskolák között 18 általános iskola, 7 középszintú képzőintézmény és 1 általános és középiskola található. A kérdôívek kitöltésére az intézményben - a tanáriban vagy a tanteremben került sor. Hiányosságok miatt egy intézményt ki kellett zárni a vizsgálatból.

A kutatásban való részvétel iskolánként eltérô: 13 intézményben $80 \%$ feletti, 9 intézményben 70 és $80 \%$ közötti, 4 intézményben pedig $70 \%$ alatti volt a részvétel. Kultúratípusok tekintetében a huszonhat intézményból 10 támogató $(\mathrm{N}=213), 2$ innovatív ( $\mathrm{N}=78)$ és 13 szabályorientált ( $\mathrm{N}=279)$ kultúrát azonosítottunk.

A minta nemi megoszlása jól szemlélteti a pedagógusi pálya egyre intenzívebb elnôiesedését: 14,5\% férfi (85 fő) és 78,4\% nô (460 fő) töltötte ki a kérdőívet, illetve a nemre vonatkozó kérdést. A kor szerinti megoszlás vizsgálata kapcsán sem találkozhatunk különösebb meglepetéssel. A válaszadók 38\%-a (223 fó) 48 évnél idôsebb, 30\%-a (177 fő) 39 és 47 év közötti, míg mindösszesen 25\% (145fő) azok aránya, akik 38 évnél fiatalabbak. A válaszadók 7\%-a nem válaszolt erre a kérdésre.

\section{AZ EREDMÉNYEK BEMUTATÁSA}

Az érzelmi intelligencia vizsgálatánál összegeztük a teljes kutatási mintát, és átlagot számítottunk (1. táblázat). Jól látható, hogy átlagosan magas értéket értek el a peda- 
gógusok az önmegvalósítás és a társas, társadalmi felelôsségvállalás dimenziókban. Az eredmények összhangban vannak Pauwlik és Margitics (2008) pedagógusjelöltekre vonatkozó megállapításaival. A pedagógusok esetében is azt találtuk, hogy a stressz kezelésében kevésbé, míg az interperszonális készségekben inkább jártasabbnak gondolják magukat a megkérdezettek.

1. táblázat: A teljes vizsgálati mintára kiterjedô érzelmiintelligencia-átlagok ( $N=572)$

\begin{tabular}{|c|c|c|c|c|c|c|c|c|c|c|c|c|c|c|c|}
\hline & 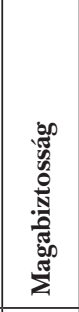 & 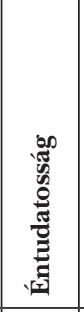 & 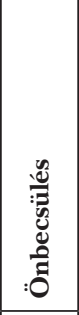 & 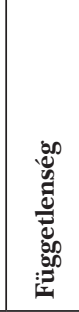 & 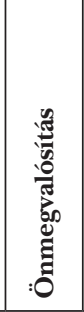 & 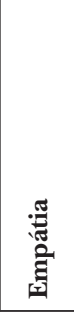 & 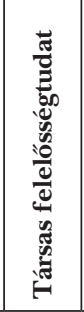 & 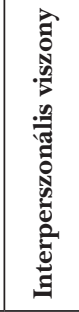 & 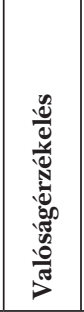 & 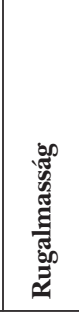 & 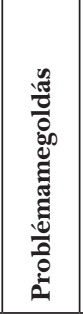 & 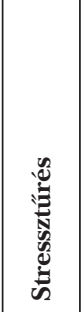 & 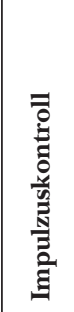 & 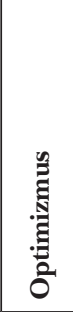 & 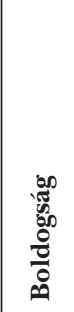 \\
\hline $\mathrm{N}$ & 557 & 553 & 554 & 557 & 550 & 555 & 560 & 554 & 554 & 562 & 563 & 558 & 547 & 552 & 552 \\
\hline Hiányzó & 15 & 19 & 18 & 15 & 22 & 17 & 12 & 18 & 18 & 10 & 9 & 14 & 25 & 20 & 20 \\
\hline Mean & 19,94 & 26,84 & 32,73 & 22,47 & 29,13 & 19,87 & 38,48 & 38,60 & 37,88 & 26,30 & 30,97 & 28,88 & 31,84 & 28,30 & 34,57 \\
\hline EMax & 30 & 35 & 45 & 35 & 35 & 25 & 45 & 50 & 50 & 40 & 40 & 45 & 45 & 40 & 45 \\
\hline$\%$ & $66 \%$ & $77 \%$ & $73 \%$ & $64 \%$ & $83 \%$ & $79 \%$ & $86 \%$ & $77 \%$ & $76 \%$ & $66 \%$ & $77 \%$ & $64 \%$ & $71 \%$ & $71 \%$ & $77 \%$ \\
\hline
\end{tabular}

Forrás: Saját szerkesztés

\section{A kultúrák közötti érzelmiintelligencia-eltérések azonosítása}

A vizsgálat során az érzelmi intelligencia fố tényezôit tekintjük a vizsgálat alapjának, így az öt készségból (intraperszonális és interperszonális készségek, stresszkezelés, alkalmazkodóképesség és általános hangulat) két dimenzióban mutatható ki az ANOVA-vizsgálattal szignifikáns eltérés. Ez a két dimenzió a stresszkezelés és az intraperszonális készségek. A részletek feltárása érdekében a metatényezókkel is elvégeztük a vizsgálatot, melynek eredménye szerint a három kultúratípus között három szignifikáns eltérést lehet meghatározni: függetlenség (,001); rugalmasság (,000); stressztúrés (,011).

A T-próba tovább pontosítja az egyes kultúratípusok közötti eltérést. A 2. táblázat ennek eredményeit foglalja össze.

Az egyének átlagos érzelmiintelligencia-eredményeinek alapján a kultúratípusok között a következó eltéréseket lehet megállapítani.

- Innovatív kultúra: átlagosan nagyobb magabiztosság, függetlenség és rugalmasság jellemzi az egyéneket. Az átlagos éntudatosság itt a legmagasabb.

- Támogató kultúra: átlagosan magas éntudatosság jellemzi, a függetlenség dimenzióban középértéket foglal el, míg a rugalmasság dimenziójában jóval az innovatív alatti, de a szabályorientált feletti értéket mutatnak az egyének. 
Balázs László: Az érzelmi intelligencia vizsgálata a szervezeti kultúra tükrében

2. táblázat: Az egyes kultúratípusok közötti eltérések az egyének érzelmiintelligenciaeredményeinek tükrében (a T-próba szignifikanciaértékei, N=572)

\begin{tabular}{|c|c|c|c|c|c|c|}
\hline & \multicolumn{2}{|c|}{ Innovatív } & \multicolumn{2}{|c|}{ Támogató } & \multicolumn{2}{|c|}{ Szabályorientált } \\
\hline & 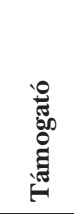 & 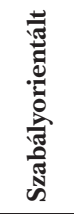 & 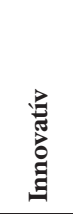 & 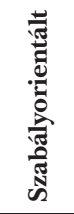 & $\begin{array}{l}\text { 导 } \\
\text { O } \\
\Xi \\
\Xi\end{array}$ & 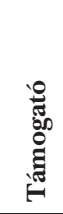 \\
\hline Magabiztosság & 102 & 040 & 102 & 559 & 040 & $\overline{5,559}$ \\
\hline Éntudatosság & 673 & ,068 & ,673 & ,053 & ,068 & ,053 \\
\hline Önbecsülés & ,370 & , 123 & ,370 &, 320 & , 123 & ,320 \\
\hline Függetlenség & 021 &, 000 & ,021 &, 067 &, 000 & 067 \\
\hline Önmegvalósítás & 689 & , 198 & 689 & 203 & , 198 & 203 \\
\hline Empátia & ,343 & ,336 & ,343 & ,973 & ,336 & ,973 \\
\hline Társas felelősségtudat & ,682 & ,893 & ,682 & ,682 & ,893 & ,682 \\
\hline Interperszonális viszony & ,091 & ,029 & ,091 & ,551 & ,029 & ,551 \\
\hline Valóságérzékelés & 625 &, 564 & ,625 & 142 &, 564 & ,142 \\
\hline Rugalmasság & 002 &, 000 & 002 & ,334 &, 000 & ,334 \\
\hline Problémamegoldás & ,969 & ,843 & ,969 & ,823 & ,843 & ,823 \\
\hline Stressztúrés & , 108 &, 004 &, 108 & ,086 &, 004 & 086 \\
\hline Impulzuskontroll & 835 &, 920 & 835 & 871 &, 920 & 871 \\
\hline Optimizmus & , 167 & ,028 &, 167 & ,250 & ,028 & ,250 \\
\hline Boldogság & 232 & ,162 & 232 & ,794 & , 162 & ,794 \\
\hline
\end{tabular}

Forrás: Saját szerkesztés

- Szabályorientált kultúra: tagjai átlagosan alacsony értékeket mutatnak a magabiztosság, éntudatosság, függetlenség, interperszonális viszony, rugalmasság és stressztúrés dimenziókban.

Célorientált kultúra nem szerepelt a vizsgálati mintában.

Összegezve a kultúrák közötti eltérést, a szabályorientált-innovatív, illetve szabályorientált-támogató kultúra között mutatható ki nagyobb eltérés az egyének érzelmi intelligenciájának átlagai alapján, míg az innovatív és támogató kultúra között kisebb különbségeket eredményeztek az elemzések.

A kultúrák sajátosságainak elkülönítését követôen az érzelmi intelligencia és a szervezeti kultúra kölcsönkapcsolatára fókuszáltunk. A közvetlen kapcsolat vizsgálatára korreláció- és regressziószámítással került sor. A korrelációszámítás alapján elmondható, hogy az érzelmi intelligencia és a quinni kultúratipológia között gyenge, szignifikáns kapcsolat azonosítható:

- a támogató kultúra az interperszonális készségekkel mutat szignifikáns, gyenge pozitív kapcsolatot;

- az innovatív kultúra a stresszkezeléssel mutat szignifikáns, gyenge pozitív kapcsolatot; 
- a szabályorientált kultúra az intraperszonális, interperszonális készségekkel, stresszkezeléssel és az általános hangulattal mutat szignifikáns, gyenge negatív kapcsolatot; - a célorientált kultúra nem mutat szignifikánsan értelmezhetó kapcsolatot, ilyen típusú kultúra nem volt a vizsgálati mintában.

A robbinsi kultúradimenziók kapcsán szintén gyenge korreláció azonosítható:

- a szervezettel/munkakörrel való azonosulás dimenzióval az interperszonális készség mutat pozitív kapcsolatot;

- a kapcsolat-/feladatorientáció dimenzióval az interperszonális készség, stresszkezelés és az alkalmazkodóképesség mutat negatív kapcsolatot;

- az erôs/gyenge kontroll dimenzióval az interperszonális készség mutat negatív kapcsolatot;

- a kockázatvállalás/-kerülés dimenzióval az intraperszonális, interperszonális készség, az alkalmazkodóképesség és az általános hangulat mutat negatív kapcsolatot, míg a stresszkezeléssel közepes negatív kapcsolatot mutat;

- a teljesítmény/egyéb kritériumok dimenzióval az alkalmazkodóképesség mutat negatív kapcsolatot;

- a konfliktustûrés/-kerülés dimenzióval az interperszonális készség, a stresszkezelés, az alkalmazkodóképesség mutat negatív kapcsolatot;

- a cél-/eszközorientáció dimenzióval az alkalmazkodóképesség mutat pozitív kapcsolatot;

- a zárt/nyílt rendszer dimenzióval a stresszkezelés és az alkalmazkodóképesség mutat pozitív korrelációt;

- a rövid/hosszú távú idôorientáció dimenzióval az interperszonális készség és a stresszkezelés mutat pozitív kapcsolatot.

A korrelációszámítás alapján a két konstruktum között kisszámú gyenge kapcsolatot lehet meghatározni. Az együttjárások azonosítását követôen a kölcsönkapcsolat feltárására törekedtünk. A kölcsönkapcsolat vizsgálatára készített regresszióvizsgálat eredményeit az alábbiak szerint foglalhatjuk össze.

\section{A szervezeti kultúra hatása az egyén érzelmiintelligencia-mintázatára}

A Robbins-féle kultúradimenziók és az érzelmi intelligencia kölcsönkapcsolatáról elmondható, hogy a kockázatvállalás/kockázatkerülés dimenzió szignifikánsan negatív hatást mutat (béta = -105 és -180 között) mind az öt fő érzelmiintelligencia-tényezőre. Ez azt jelenti, hogy a kockázatvállaló kultúra hozzájárul, támogatja az érzelmiintelligencia-értékek növekedését. Három dimenzió mutat még értelmezhetô eredményt. Ezek a következôk:

- a nyílt rendszer támogatja az alkalmazkodóképesség kialakulását, fejlődését;

- a teljesítménykritérium alapján történó értékelés hozzájárul az intraperszonális készségek növekedéséhez;

- a konfliktuskerülés növeli az általános hangulatot.

Az eredményekkel kapcsolatban fel kell hívni a figyelmet arra, hogy ez a modell az értékek változásának kis mértékét magyarázza $\left(\mathrm{r}^{2} \sim=0,05\right)$, ugyanakkor a két konst- 
ruktum között a kapcsolat bizonyítottan fennáll: $\mathrm{f}<0,05$. Az eredményeket az érzelmi intelligencia 15 metatényezôjére kiterjesztett vizsgálat is igazolta - a kockázatvállalás/-kerülés dimenzió erôs szignifikancia mellett gyakorol hatást az érzelmi intelligencia metatényezóire - kivétel: az optimizmus, az impulzuskontroll, a problémamegoldás és a társas felelôsségtudat. Az 1. ábra a szervezeti kultúra hatását szemlélteti az érzelmi intelligencia fố tényezôire.

1. ábra: A szervezeti kultúra közvetlen hatása az érzelmi intelligenciára (béta-értékekkel)

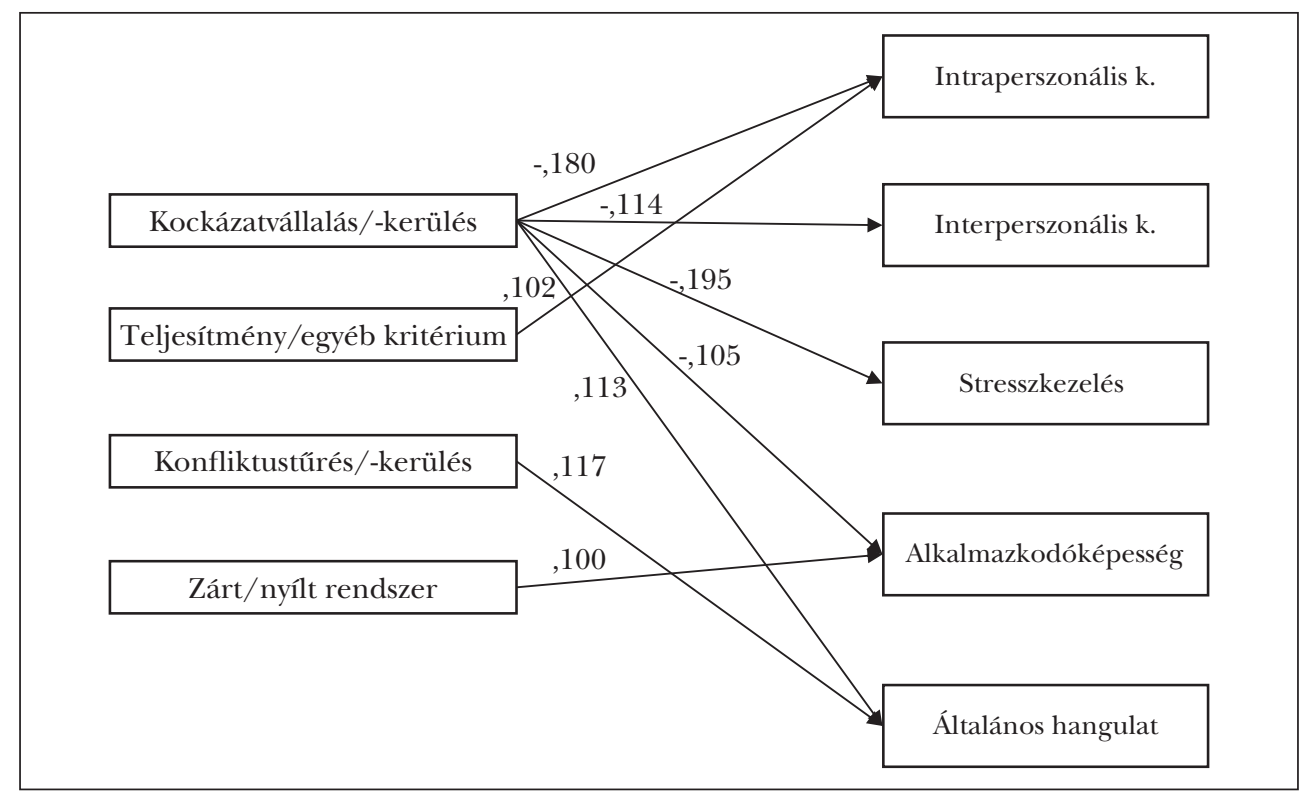

Forrás: Saját szerkesztés

\section{Az érzelmi intelligencia hatása a szervezeti kultúrára}

Az érzelmi intelligencia fớ tényezôi mentén is elvégeztük a regressziószámítást, vizsgálva, hogy a fố tényezôk gyakorolnak-e hatást a szervezeti kultúra egyes dimenzióira. Ennél a vizsgálatnál a hatásfolyamat magyarázatára elsôsorban mint lehetôségre kell tekinteni. Az érzelmiintelligencia-tényezôk megléte vagy meg nem léte értelemszerúen nem eredményezi egy adott kultúrajellemzó, kultúradimenzió kialakulását vagy eltúnését. Ugyanakkor a kapcsolatból lehet következtetéseket levonni arra, hogy az adott érzelmiintelligencia-tényezô megléte elôsegíti, erôsíti-e az adott kultúrajellemzô kialakítását, fejlôdését. A következô eredményeket kaptuk:

- Az egyénközpontúság/csoportközpontúság dimenzióra a stresszkezelés fố tényezô gyakorol hatást. Eszerint a stresszkezelés növekedése hozzájárul a szervezetben az egyénközpontúság kialakulásához.

- Az erôs/gyenge kontroll dimenzióra két fố tényezô szignifikáns, egy pedig közel szignifikáns hatást mutat. Az interperszonális készségek és az alkalmazkodóképesség 
növekedése az erôs kontroll kialakulását, növekedését segíti, segítheti elő; a stresszkezelés növekedése pedig a gyenge kontroll fejlődését támogatja. Minél jobban tudja valaki kezelni a stresszt - minél magasabb stresszkezelésértékkel rendelkezik -, annál kevésbé érzi szorítónak, erôsnek a kontrolláltságot.

- A stresszkezelés növekedése hozzájárul a kockázatvállalás erôsödéséhez. Tehát minél jobban tudja kezelni a stresszt, annál jobban képes a kockázatvállalásra, az ilyen típusú kultúra kialakítására.

- A zárt/nyílt rendszer dimenzióra az alkalmazkodóképesség gyakorol hatást. Az alkalmazkodóképesség növekedése hozzájárul a nyílt rendszer erősödéséhez, fejlődéséhez.

Az érzelmi intelligenciának a szervezetikultúra-dimenzióira gyakorolt hatását szemlélteti a 2. ábra.

\section{2. ábra: Az érzelmi intelligencia közvetlen hatása a szervezeti kultúrára (béta-értékekkel)}

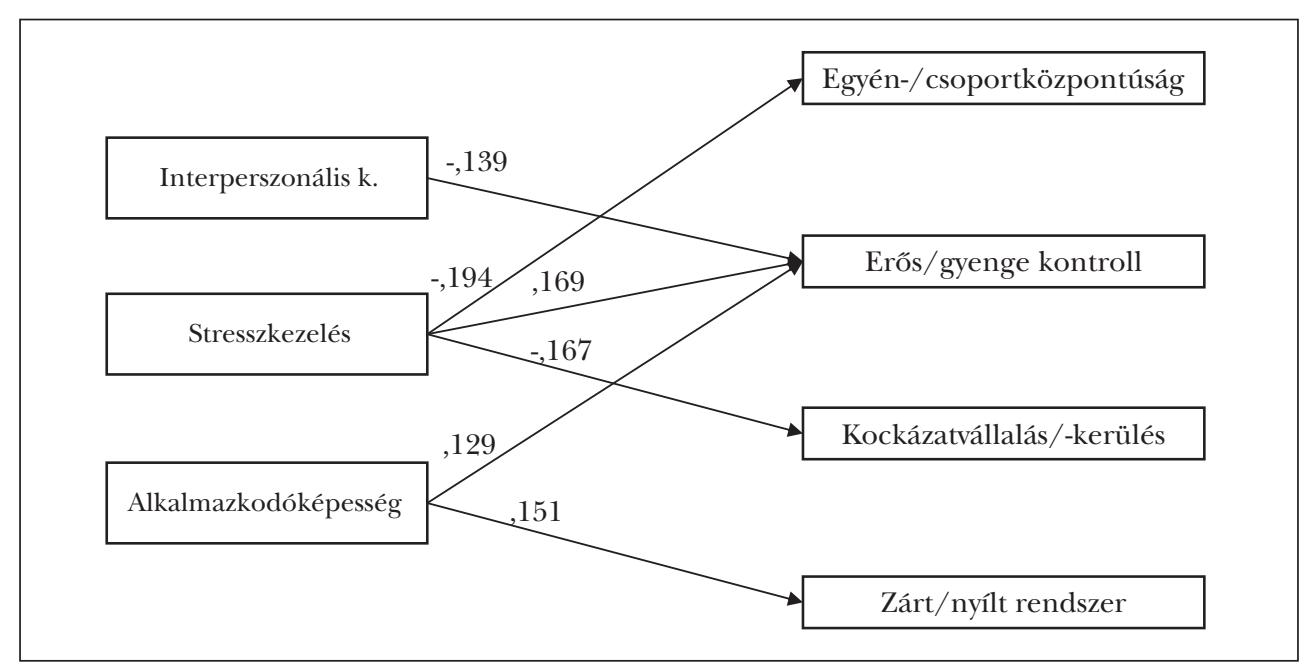

Forrás: Saját szerkesztés

Az érzelmi intelligencia és a szervezeti kultúra kölcsönkapcsolatának vizsgálata során több olyan tényezốt sikerült azonosítani, melynek változása hatással van másik tényezô alakulására. Az elemzés során olyan tényezôket is azonosítottunk, melyek kölcsönösen fejtik ki hatásukat. A két konstruktum közötti hatásmechanizmust szemlélteti a 3. ábra.

\section{ÖsSZEGZÉs}

A vizsgálat igazolta, hogy az egyes kultúratípusok között különbséget lehet tenni a szervezeti tagok átlagos érzelmiintelligencia-mintázatában. Emellett a szervezeti kultúra és az érzelmi intelligencia kölcsönkapcsolatának vizsgálata során azt találtuk, hogy az érzelmi intelligencia és a szervezeti kultúra dimenziói között közvetlen kölcsönkap- 
3. ábra: A szervezeti kultúra és az érzelmi intelligencia fố tényezôinek hatásmechanizmusa (fekete: EI $\rightarrow$ kultúra; vékony szürke: kultúra $\rightarrow$ EI; vastag szürke: kölcsönhatás; béta-értékekkel)

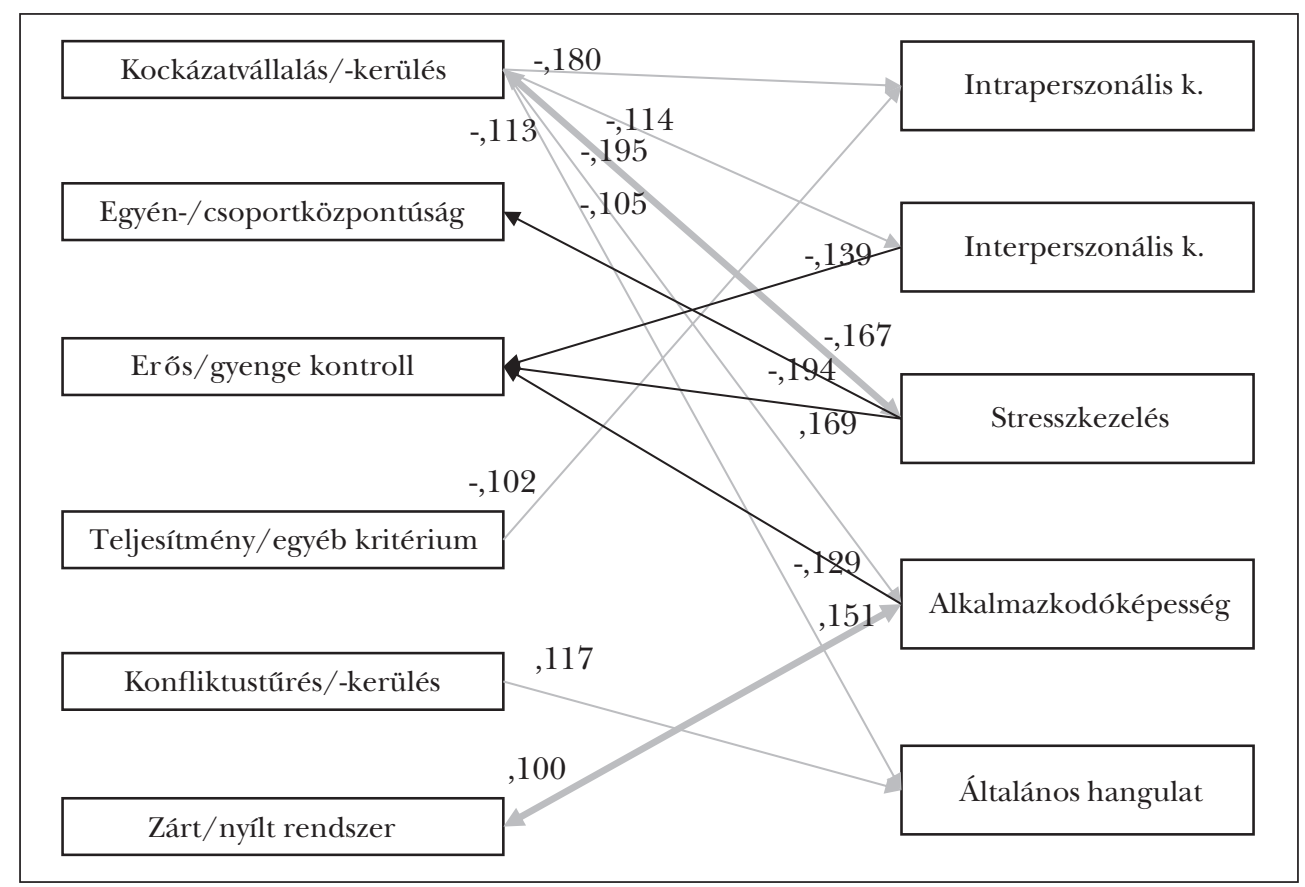

Forrás: Saját szerkesztés

csolat mutatható ki. Ennek a kölcsönkapcsolatnak a jellegzetessége, hogy a szervezeti kultúra kockázatvállalás-kockázatkerülés dimenziója - egyéb tényezôk mellett - markáns hatást gyakorol az öt fố érzelmiintelligencia-tényezôre, míg az érzelmi intelligencia fớ tényezôi közül a stresszkezelés fejti ki legmarkánsabban a hatását. Az eredmények alátámasztják azon felvetést, hogy az érzelmi intelligencia és a szervezeti kultúra múködése és jelenléte kölcsönösen befolyásolják egymást, hatásukat közvetlenül is kifejtik.

Az érzelmi intelligencia és a szervezeti kultúra közötti összefüggés feltárásával lehetôség kínálkozik a szervezetben zajló folyamatok tudatosabb, célorientáltabb szervezésére, átalakítások dinamikusabb elômozdítására, legyen szó az oktatás-nevelés folyamatának tudatosításáról (vö. Balázs, 2014), fejlesztéséról, vagy az iskolai szervezet múködésének dinamizálásáról.

Az iskolai környezetben történó érzelmiintelligencia-fejlesztés több hasznos hozadékkal szolgálhat az intézmény számára: erôsíti a szervezeti kultúrát, a pedagógusok mintaadásával közvetetten fejleszti a diákok érzelmi intelligenciáját, mely bizonyítottan jobb tanulmányi eredményhez vezet, erôsíti a kollektívát, és javítja a szervezeti klímát (vö. Zeidner et al., 2009). 


\section{Polgári Szemle · 16. évfolyam 1-3. szám}

\section{FELHASZNÁLT IRODALOM}

Arshad, Muhammad (2003): A Study of Organizational Culture and Effectiveness of Secondary Schools. PhD Thesis, University of Punjab, Lahore.

Bakacsi Gyula (2015): A szervezeti magatartás alapjai. Alaptankönyv Bachelor hallgatók számára. Semmelweis Kiadó, Budapest.

Balázs László (2013): A szervezeti kultúra és az érzelmi intelligencia kölcsönkapcsolatának vizsgálata az iskolában. PhD-értekezés, Pécsi Egyetem BTK, Pécs.

Balázs László (2014): Érzelmi intelligencia a szervezetben és a képzésben. Z-Press Kiadó, Miskolc.

Baracsi Ágnes (2013): Pedagógusok érzelmi intelligenciája. In: Vzdelávanie, výskum a metodológia. Intern. Research Institute, Komárno, 480-488, www.irisro.org/pedagogia2013januar/0511BaracsiAgnes.pdf (Letöltés: 2020. március 11.).

Bar-On, Reuven (2006): The Bar-On Model of Emotional-Social Intelligence. Psicothema, Vol. 18, No. 1, 13-25.

Baráth Tibor (1998): Hatékonyságmodellek a közoktatásban. In: Budai Ágnes - Varga Lajos (szerk.): Közoktatás-kutatás 1996-1997. Mûvelődési Minisztérium, Budapest, www.staff.u-szeged.hu/ barath/tanulm/ BESZV.htm.

Bíró Balázs - Serfôzô Mónika (2003): Szervezetek és kultúra. In: Hunyady György - Székely Mózes (szerk.): Gazdaságpszichológia. Osiris Kiadó, Budapest.

Coetzee, Melinda - Jansen, Cecelia (2007): Emotional Intelligence in the Classroom. Juta and Company, Claremont.

Darwin, Charles (1859/2000): A fajok eredete. Typotex, Budapest.

Ekman, Paul (1989): The Argument and Evidence about Universals in Facial Expressions of Emotion. In: Wagner, Hugh - Manstead, Anthony (eds.): Handbook of Social Psychophysiology. John Wiley, Chichester.

Forgács József (szerk.) (2001): Érzelem és gondolkodás. Kairosz Kiadó, Budapest.

Forgács József (2003): Az érzelmek pszichológiája. Kairosz Kiadó, Budapest.

Gaziel, Haim H. (1997): Impact of School Culture on Effectiveness of Secondary Schools With Disadvantaged Students. The Journal of Educational Research, Vol. 90, No. 5, 310-318, https://doi.org/10.1080/ 00220671.1997.10544587.

Geertz, Clifford (1973/1994): Sưrú leírás. In: Geertz, Clifford: Az értelmezés hatalma. Századvég Kiadó, Budapest, 170-216.

Gibson, Donald (2006): Emotional Episodes at Work: An Experiential Excercise in Feeling and Expressing Emotions. Journal of Management Education, Vol. 30, No. 3, 477-500, https://doi.org/10.1177/ 1052562905282016.

Goffee, Rob - Jones, Gareth (1998): The Character of a Corporation. How Your Company's Culture Can Make or Break Your Business. HarperCollins, New York.

Goleman, Daniel (2001): Emotional Intelligence: Issue in Paradigm Building. In: Cherniss, Cary - Goleman, Daniel (eds.): The Emotionally Intelligent Workplace. How to Select for, Measure, and Improve Emotional Intelligence in Individuals, Groups and Organizations. Jossey-Bass, San Francisco, 13-26.

Halász Gábor (1980): Az iskolai szervezet elemzése. Kutatási beszámoló az iskolai szervezeti klíma vizsgálatáról. MTA Pedagógia Kutatócsoport, Budapest.

Hegyiné Ferch Gabriella (2001): Az érzelmi intelligencia szerepe a nevelői munkában. Új Pedagógiai Szemle, 51. évf., 7-8. sz., 8-19.

Hegyiné Ferch Gabriella (2009): Az érzelmi intelligencia szerepe a nevelói munkában. www.ofi.hu/tudastar/ erzelmi-intelligencia (Letöltés: 2020. március 19.).

Herriford, Olivia S. (2002): High-technology Organizational Culture and Emotional Intelligence. Dissertation, University of Phoenix.

Higgs, Malcolm - Dulewicz, Victor (1999): Making Sense of Emotional Intelligence. NFER-Nelson, Windsor.

Higgs, Malcolm - McGuire, Mary (2001): Emotional Intelligence and Culture: an Exploration of the Relationship Between Individual Emotional Intelligence and Organisational Culture. Henley Working Paper Series, Henley Management College. 


\section{Balázs László: Az érzelmi intelligencia vizsgálata a szervezeti kultúra tükrében}

Hofstede, Geert - Hofstede, Gert J. (2008): Kultúrák és szervezetek. Az elme szoftvere. VHE Kft., Pécs.

Kádár Annamária (2012): Az érzelmi intelligencia fejlődése és fejlesztésének lehetôségei óvodás-és kisiskoláskorban. Ábel Kiadó, Cluj-Napoca.

Kovács J. (1996): Vezetốk és menedzserek a közoktatásban - avagy vezetôi szerepfelfogások és szervezeti kultúrák. Magyar Pszichológiai Társaság Nagygyúlése. ELTE, Budapest.

Kovács Zoltán - Perjés István - Sass Judit (2005): Iskolák szervezeti kultúrája. In: Faragó Klára - Kovács Zoltán (szerk.): Szervezeti látleletek. A szervezetpszichológia hazai kutatási irányai. Akadémiai Kiadó, Budapest, 51-64.

Lazányi Kornélia (2011): Érzelmek a munkahelyen. Vezetéstudomány, 42. évf., 4.sz., 46-61.

Levy, Robert I. (1984): Emotion, Knowing, and Culture. In: Shweder, Richard - LeVine, Robert (eds.): Culture Theory. Cambridge University Press, Cambridge, 214-237.

Lutz, Catherine (1986): Emotion, Thought, and Estrangement: Emotion as a Cultural Category. Cultural Anthropology, Vol. 1, No. 3, 287-309, https://doi.org/10.1525/can.1986.1.3.02a00020.

Mészáros Aranka (szerk.) (2002): Az iskola szociálpszichológiai jelenségvilága. ELTE Eötvös Kiadó, Budapest.

Mortiboys, Alan (2005): Teaching with Emotional Intelligence. Routledge, London, https://doi. org/10.4324/9780203087794.

Nagy Henriett - Oláh Attila - G. Tóth Kinga (2009): Az érzelmi intelligencia mérésének néhány problémája: a fejlődési kritérium tesztelése. Pszichológia, 29. évf., 2. sz., 165-186.

Oláh Attila (2005): Érzelmek, megküzdés és optimális élmény. Trefort Kiadó, Budapest.

Pauwlik Zsuzsa - Margitics Ferenc (2008): Pedagógusjelöltek érzelmi intelligenciája. Új Pedagógiai Szemle, 6-7. sz.

Payne, Roy L. - Cooper, Cary (2004): Emotions At Work. Theory, Research and Applications for Management. Wiley and Sons.

Pérez, Juan C. - Petrides, K. V. - Furnham, Adrian (2005): Measuring Trait Emotional Intelligence. http:// portal.uned.es/pls/portal/docs/page/uned_main/launiversidad/ubicaciones/03/docente/juan_carlos_perez_gonzalez/p\%c3\%89rez,\%20petrides,\%20\%26\%20furnham,\%202005.pdf (Letöltés: 2020. február 26.).

Péter-Szarka Szilvia - Fehér Ágota (2012): Iskolai zaklatás a tanári érzelmi intelligencia és az iskolai klíma tükrében. In: Interdiszciplináris pedagógia és a felsôoktatás alakváltozásai. Kiss Árpád Archivum Könyvsorozata, Debreceni Egyetem Neveléstudományok Intézete, Debrecen.

Quinn, Robert E. - Rohrbaugh, John (1983): A Spatial Model of Effectiveness Criteria: Towards a Competing Values Approach to Organizational Analysis. Management Science, Vol. 29, No. 3, 363-377.

Roberts, Richard D. - MacCann, Carolyn - Matthews, Gerald - Zeidner, Moshe (2010): Emotional Intelligence: Toward a Consensus of Models and Measures. Social and Personality Psychology Compass, Vol. 4, No. 10, 821-840, https://doi.org/10.1111/j.1751-9004.2010.00277.x.

Serfôzố Mónika (2002): A szervezeti kultúra fogalmának, modelljeinek értelmezése az óvodában, iskolában. In: Mészáros Aranka (szerk.): Az iskola szociálpszichológiai jelenségvilága. ELTE Eötvös Kiadó, Budapest, 381-397.

Serfôzó Mónika (2005): Az iskolák szervezeti kultúrája. Iskolakultúra, 15. évf., 10. sz., 70-83.

Spielberger, Charles (2004) (ed.): Encyclopedia of Applied Psychology. Academic Press, Cambridge, USA.

Szabolcsi Ferenc (1996): A szervezeti kultúra sajátosságai az iskolában. Iskolakultúra, 6. évf., 5. sz., 85-90.

Szitó Imre (2009): Az érzelmi intelligencia fejlesztése az iskolában. Edition Nove Kiadó, Sopron.

Wang, Hsi-Kong Chin - Hwang, Feng-Chan (2007): Study on Organizational Culture, Organizational Commitment and Attitude toward Organizational Reform - Comprehensive High Schools as Example. The Journal of Human Resource and Adult Learning, Vol. 3, No. 2.

Zeidner, Moshe - Matthews, Gerald - Roberts, Richard D. (2009): What We Know about Emotional Intelligence. The MIT Press, Cambridge, London, https://doi.org/10.7551/mitpress/7404.001.0001. 